\title{
Batrachochytrium dendrobatidis infection dynamics in the Columbia spotted frog Rana luteiventris in north Idaho, USA
}

\author{
Danelle M. Russell ${ }^{1,2}$, Caren S. Goldberg ${ }^{1}$, Lisette P. Waits ${ }^{1}$, Erica Bree Rosenblum ${ }^{2, *}$ \\ ${ }^{1}$ Fish and Wildlife Resources, University of Idaho, Moscow, Idaho 83844-1136, USA \\ ${ }^{2}$ Department of Biological Sciences, University of Idaho, Moscow, Idaho 83844-3051, USA
}

\begin{abstract}
The pathogenic chytrid fungus Batrachochytrium dendrobatidis $(B d)$ is contributing to amphibian declines worldwide. Temperature plays an important role in both pathogen growth and host immune function, but little is known about seasonal dynamics of $B d$ infection in north temperate regions. Our objective was to increase understanding of $B d$ disease ecology by investigating patterns of $B d$ infection of Columbia spotted frogs Rana luteiventris across seasons, age classes, and sexes in north Idaho, USA. We collected skin swabs from 223 R. luteiventris in spring, summer, and fall 2009 at 7 ponds in the Palouse region and quantified $B d$ zoospores for each sample using quantitative PCR. Across seasons, $B d$ prevalence of adults was higher in summer than in spring or fall, suggesting that individuals may be clearing low-level infections over the summer. Among age classes, all but one late stage tadpole (Gosner stage 43-45) tested negative for Bd. Conversely, $100 \%$ of metamorphs tested positive for $B d$ and had the highest $B d$ loads of all age classes, suggesting they may be the most vulnerable age class. Adult $R$. luteiventris had high infection prevalence $(>60 \%)$ in all seasons, indicating that $B d$ infection is maintained within populations and that adults likely serve as disease reservoirs across seasons. Among adults, we also found weak evidence for females having higher infection prevalence than males. Further laboratory and field studies are needed to determine whether there are individual and population impacts from $B d$ on $R$. luteiventris and other amphibians in north Idaho.
\end{abstract}

KEY WORDS: Amphibian declines - Batrachochytrium dendrobatidis - Chytrid - Idaho · Rana luteiventris

Resale or republication not permitted without written consent of the publisher

\section{INTRODUCTION}

Chytridiomycosis is a skin disease of amphibians caused by the chytrid fungus Batrachochytrium dendrobatidis (hereafter $B d$ ). This chytrid pathogen has infected hundreds of amphibian species worldwide and has caused mass mortalities, population declines, and extinctions (e.g. Berger et al. 1998, Lips et al. 2006, Schloegel et al. 2006). The origin of $B d$ is unknown, but evidence suggests that $B d$ is an emerging pathogen (Morehouse et al. 2003, James et al. 2009) and can spread quickly after introductions to new regions (Mazzoni et al. 2003, Pearl et al. 2007, Kriger \& Hero 2008, Picco \& Collins 2008).
Temperature is an important driver of $B d$ dynamics because both $B d$ growth and frog immune response are temperature dependent. In laboratory settings, $B d$ has an optimal range of temperature conditions for growth (17 to $25^{\circ} \mathrm{C}_{i}$ Piotrowski et al. 2004), and field studies have shown that infection dynamics in nature can be correlated with temperature and climatic conditions (Berger et al. 2004, Kriger \& Hero 2008). Bd does not easily survive sustained temperatures above $30^{\circ} \mathrm{C}$ (Piotrowski et al. 2004), and laboratory experiments have shown that some frog species are capable of clearing $B d$ infection at temperatures above $29^{\circ} \mathrm{C}$ (Woodhams et al. 2003). Amphibian immune responses are also strongly affected by temperature (Maniero \& 
Carey 1997), so temperature likely plays an important role in host response as well as pathogen growth.

Regions with highly seasonal climates can be especially informative for understanding the role of temperature in mediating $B d$ host-pathogen dynamics. In seasonal temperate environments, there is often a narrow window in which climatic conditions are optimal for $B d$ growth (although microhabitat use may extend this window to some extent). Additionally, in seasonal environments amphibian immune function is likely to be suppressed during and immediately following hibernation due to lower temperatures (Maneiro \& Carey 1997). Thus, it is unclear if there is a predictable net effect of seasonality on $B d$ infection dynamics. Many of the most dramatic $B d$-related die-offs have occurred in tropical environments (e.g. Lips et al. 2006), but there are also documented die-offs in highly seasonal temperate environments, e.g. Rana muscosa in California, USA (Briggs et al. 2005), and Bufo boreas in Colorado, USA (Muths et al. 2003). To achieve a more complete understanding of the relationship between seasonality, host response and pathogen growth it is important to quantify the dynamics of $B d$ infection in additional natural settings.

In addition to understanding the effects of seasonality, further data are needed to understand differences in infection dynamics across demographic groups in natural populations. Differences in $B d$ infection dynamics among age classes are likely given developmental differences in skin composition and immune function. For example, amphibian skin is not keratinized in tadpoles (Gosner 1960), and immune function is not mature until well after metamorphosis (Flajnik et al. 1987). Documenting differences in $B d$ dynamics across amphibian age classes is thus important for understanding life-stage specific disease vulnerability. Similarly, differences in $B d$ infection dynamics between sexes are possible in some amphibian species because of sex-specific behaviors that can increase disease transmission, such as differential use of substrates or aggregation during the breeding season (e.g. Rowley \& Alford 2007). Differences in Bd impacts between sexes could have important implications for reproduction and inbreeding, especially for species with small population sizes and/or biased sex ratios. Thus, studying patterns of $B d$ infection across sexes and age classes can provide information critical to predicting disease-related impacts on amphibian populations.

The Columbia spotted frog Rana luteiventris is an informative model species for studying $B d$ patterns across seasons, sexes, and age classes in north temperate habitats. $R$. luteiventris has an extensive distribution in western North America (including southern Alaska, British Columbia, western Alberta, Oregon, Washington, Idaho, Montana, Wyoming, Utah, and
Nevada), occupies a variety of habitats ranging from sagebrush benches to subalpine forests, and is found at elevations from sea level to $2700 \mathrm{~m}$ (Reaser \& Pilliod 2005). The conservation status of $R$. luteiventris varies regionally; populations in some regions are relatively large while those in other regions have been considered for listing under the Endangered Species Act (Reaser \& Pilliod 2005). In the Palouse region of north Idaho, breeding populations are often small and isolated, which may make $R$. luteiventris vulnerable to the genetic consequences of inbreeding and extirpation by pathogens (Davis \& Verrell 2005). Breeding sites in this area were first tested for $B d$ in 2004; $B d$ was detected at all 10 sites sampled (C. S. Goldberg \& L. P. Waits unpubl. data) although no amphibian population declines have been documented in this region. Opportunities for $B d$ transmission between populations may be frequent, as $R$. luteiventris has relatively high levels of movement among ponds in this area (Goldberg \& Waits 2010). Additionally, R. luteiventris inhabits a highly seasonal environment and the large differences in temperature among seasons in this region may mediate $B d$ infection dynamics. Given its variable conservation status and the documented presence of $B d$, field studies are important for understanding the role $B d$ plays in the population dynamics of this species and other pond-breeding amphibians in seasonal environments. Thus, we examined the prevalence and intensity of $B d$ infection in $R$. luteiventris populations in north Idaho ponds. Specifically, we evaluated $B d$ prevalence and intensity across (1) seasons, (2) age classes, and (3) sexes.

\section{MATERIALS AND METHODS}

Sampling. We sampled 223 Rana luteiventris (adults, metamorphs, and late stage tadpoles) from 7 ponds in Latah County, Idaho over 3 seasons in 2009 (spring, summer, and fall; Table 1, see Fig. 1). We chose study sites to cover a range of elevations (774 to $1341 \mathrm{~m}$; determined using a $30 \mathrm{~m}$ digital elevation model). Lower elevation sites were surrounded by wheat fields, and

Table 1. Rana luteiventris. Summary of sample sizes swabbed for Batrachochytrium dendrobatidis by developmental stage and sampling season. Samples were collected in 7 ponds in Latah County, Idaho, USA, in 2009

\begin{tabular}{|lccc|}
\hline Season & Adult & Late stage tadpole & Metamorph \\
\hline Breeding & 108 & 0 & 0 \\
Summer & 53 & 23 & 0 \\
Fall & 18 & 0 & 21 \\
Total & 179 & 23 & 21 \\
\hline
\end{tabular}


higher elevation sites were surrounded by coniferous forest. The ponds were all less than 1 acre (ca. 0.4 ha) in area and varied in volume seasonally ( 2 ponds were ephemeral). We collected $R$. luteiventris using minnow traps and dip-nets. We handled frogs with unused, non-powdered latex gloves to prevent disease transmission and swab contamination. We sampled $R$. luteiventris at each pond once during each of the 3 seasons with a target of sampling 10 to 15 frogs per pond per season. To ensure that frogs were not sampled more than once in a season, sampling was generally restricted to a single day per pond. We held all frogs in individual plastic bags until all sampling was complete for the day, and if we reached our target sample size, no further sampling took place. If fewer than 10 frogs were caught in a single day, we marked captured frogs by clipping one toe-tip to ensure it would not be resampled if we recaptured it the same season. Pond water temperature was measured during each visit using a thermometer placed $1 \mathrm{ft}(\mathrm{ca} .30 \mathrm{~cm})$ below the water surface.

We sampled frogs in 2 broad age classes: adults and young of the year. Adults had undergone at least $1 \mathrm{yr}$ of overwintering, although they may not be sexually mature until 2 to 6 yr of age (Reaser \& Pilliod 2005). We sexed adults when diagnostic characteristics were apparent. Males typically are much smaller in size compared to females and have large nuptial pads at the base of their thumbs (Patla \& Keinath 2005). Young of the year were further categorized as 'late stage tadpoles' and 'metamorphs'. The late stage tadpoles were Gosner stage 43-46; these late stage tadpoles had a developed mouth and both hind and forelimbs, but still possessed a tail or tail stub (Gosner 1960). Bd attacks only the keratinized tissues of the frog; at stage 43-46 the skin is only keratinized in localized areas on the sides, feet, and tail (Berger et al. 1998, Marantelli et al. 2004). Although detectability of $B d$ may vary by developmental stage, late stage tadpoles exposed to $B d$ consistently show infection on their limbs detectable by swabbing and quantitative PCR (qPCR) (Garner et al. 2009). Other studies have shown that high $B d$-related mortality typically occurs soon after metamorphosis (Rachowicz et al. 2006, Kriger \& Hero 2008, Garner et al. 2009). Therefore, we were particularly interested in metamorphs and adults as the primary reservoirs for $B d$ and metamorphs as a potentially vulnerable age class. Late stage tadpoles were also included because we were interested in $B d$ dynamics during the transition from late stage tadpole to early metamorph.

We sampled in each of 3 seasons: spring, summer, and fall. Our spring sampling (March-June) coincided with the Rana luteiventris breeding season. Because breeding time varies by elevation, we sampled each pond at the peak of its breeding season. During our spring surveys, only adults were sampled because young of the year were not yet present. Our summer sampling (July-August) occurred during tadpole metamorphosis. During our summer surveys adults and late stage tadpoles were sampled. Our fall sampling (October) was just prior to overwintering. Thus, during our fall surveys, adults and metamorphs were sampled (all tadpoles had completed metamorphosis). Therefore, adults were collected in all 3 seasons, late stage tadpoles were only present in the summer and metamorphs were only present in the fall.

For each frog sampled, we recorded season, sex and age class and took a swab sample to measure $B d$ infection load. We swabbed each frog by firmly running a sterile swab (MW 100-100, Medical Wire \& Equipment) 10 times over the frog's dorsal surface, each of the frog's sides (from groin to armpit), and the ventral surface and 5 times on the undersides of each thigh and on the undersides of each foot, for a total of 70 strokes per individual (Kriger et al. 2006a). The swabs were placed in individual sterilized tubes and frozen at $-20^{\circ} \mathrm{C}$ within $6 \mathrm{~h}$ of sampling to prevent DNA degradation.

Laboratory methods. We used established qPCR techniques to assess whether $B d$ was present on frogs in each pond sampled (prevalence) and the number of zoospore equivalents on infected frogs (intensity). We extracted DNA from swabs using a Prepman Extraction kit (Boyle et al. 2004; Applied Biosystems) and used an Applied Biosystems 7500 Fast Real-Time quantitative PCR System (Applied Biosystems) to quantify $B d$ intensity following a protocol modified from Boyle et al. (2004). The following changes were made to the conditions in Boyle et al. (2004): total reaction volume was $10 \mu \mathrm{l}$, probe concentration was $125 \mathrm{nM}$, and 1 out of the 3 wells for each sample contained the internal control recommended by Hyatt et al. (2007) to ensure there was no inhibition of the reaction. The Australian Animal Health Laboratory (Geelong, Victoria, Australia) provided the quantification standards. Any sample yielding ambiguous results (testing positive for 1 or 2 replicates) was rerun and considered positive only if another positive detection occurred (following Kriger et al. 2006b). We report intensity as the mean number of zoospores detected in all replicates for an individual swab. A negative control with all standard reagents was included in each extraction to confirm that there was no contamination.

Data analysis. We analyzed patterns of $B d$ infection (i.e. prevalence and intensity) between sexes and among age classes and seasons using generalized linear models (GLMs) with pond as a random effect. We conducted GLMs for $B d$ prevalence and $B d$ intensity separately. The objective of the GLM analyses was to determine the contribution of each fixed effect (i.e. sex, age class, season) after accounting for the random 
effect (i.e. differences between ponds). Because age class for young of the year was confounded with season (i.e. tadpoles were only present in summer and metamorphs were only present in fall), we analyzed only adult samples in tests of differences among seasons. We determined significance for each fixed effect separately using a likelihood ratio test between the model with both the fixed and random effect and a model with just the random effect. We conducted our GLM analyses separately for each fixed effect but we also evaluated whether age class and season jointly explained patterns of $B d$ infection better than either variable alone. To determine whether both age class and season contributed to explaining patterns of $\mathrm{Bd}$ prevalence and intensity (while accounting for uneven sampling from ponds), we constructed a set of candidate hypotheses and ranked the evidence for each using Akaike's Information Criterion (AIC) (Burnham \& Anderson 2003). Finally, we used simple linear regression to test if water temperature or elevation could explain variation in $B d$ prevalence and average intensity at ponds. We determined 95\% confidence intervals (CI) for prevalence data using the relationship between the $F$ distribution and the binomial distribution (Zar 1984). For analyses of intensity, we log-transformed the data to better meet assumptions of normality. Statistical analyses were performed using JMP software (SAS, Cary, NC, USA) and package lme4 in R (Bates 2005, R Development Core Team 2008).

\section{RESULTS}

We found that Rana luteiventris from all 7 surveyed pond sites were infected with $B d$, with prevalence varying from 35 to $100 \%$ (Fig. 1). We found strong evidence that both age class and season affected patterns of $B d$ infection, weak evidence that females had higher $B d$ prevalence than males, and no evidence of a relationship between patterns of $B d$ and environmental variables. These findings are detailed below.

\section{Sex}

We found weak evidence that $B d$ prevalence varied between sexes after accounting for pond differences $\left(\chi^{2}{ }_{1}=\right.$ $3.09, \mathrm{p}=0.08)$. Females had an average prevalence of $87.0 \%(95 \% \mathrm{CI}=66.4$ to
$97.2 \%$ ) and males had an average prevalence of $65.3 \%$ (95\% CI $=56.4$ to $73.6 \%$ ). There was no evidence that intensity differed between the sexes $\left(\chi^{2}{ }_{1}=0.015, \mathrm{p}=\right.$ 0.90; mean for females $=94$ zoospores, $95 \% \mathrm{CI}=37$ to 240 zoospores; mean for males = 69 zoospores, $95 \%$ $\mathrm{CI}=44$ to 107 zoospores).

\section{Age class}

We found that both $B d$ prevalence and intensity varied among age classes. $B d$ prevalence showed strong differences among life stages after accounting for pond differences $\left(\chi^{2}{ }_{2}=44.39\right.$, $\left.\mathrm{p}<0.001\right)$ with metamorphs having the highest infection prevalence (Fig. 2). Averaging across all seasons, $67.6 \%$ of the adults (121/179), $100 \%$ of metamorphs (23/23), and $4.8 \%$ of late stage tadpoles $(1 / 21)$ tested positive for $B d$. $B d$ intensity for infected individuals also differed among age classes after accounting for pond $\left(\chi_{2}^{2}=0.015, \mathrm{p}<0.001\right.$; Fig. 3 ). Metamorphs had a higher infection intensity (mean = 490 zoospores, $95 \% \mathrm{CI}=212$ to 1133 zoospores) than adults (80 zoospores, $95 \% \mathrm{CI}=55$ to 116 zoospores) and late stage tadpoles ( $\mathrm{n}=1$ positive, 10 zoospores).

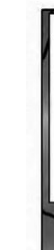

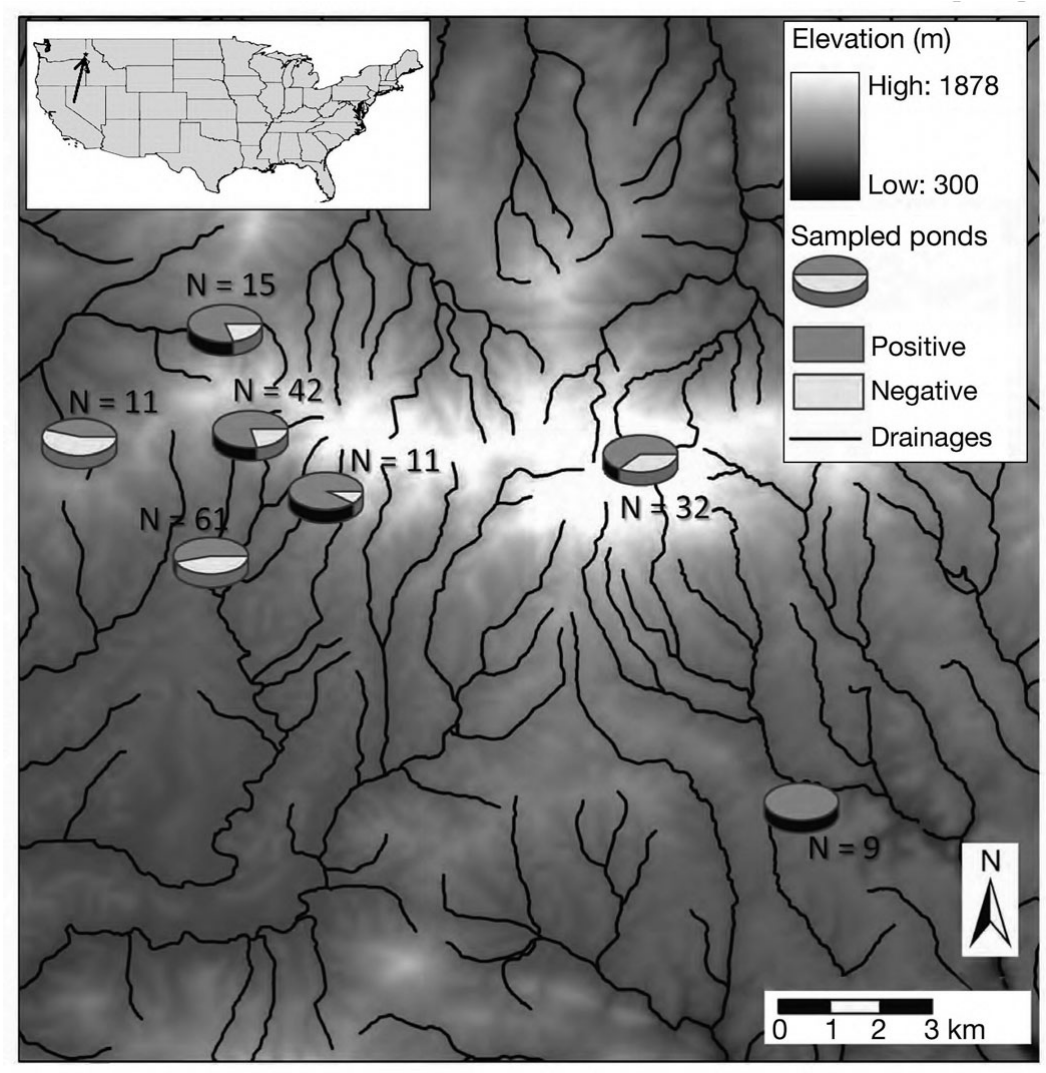

Fig. 1. Geographic distribution of ponds sampled for Batrachochytrium dendrobatidis $(B d)$ in Latah County, north Idaho, 2009. For each pond, the number of adult Rana luteiventris sampled $(\mathrm{N})$ is shown adjacent to a pie chart displaying the proportion of $B d$-infected adults 


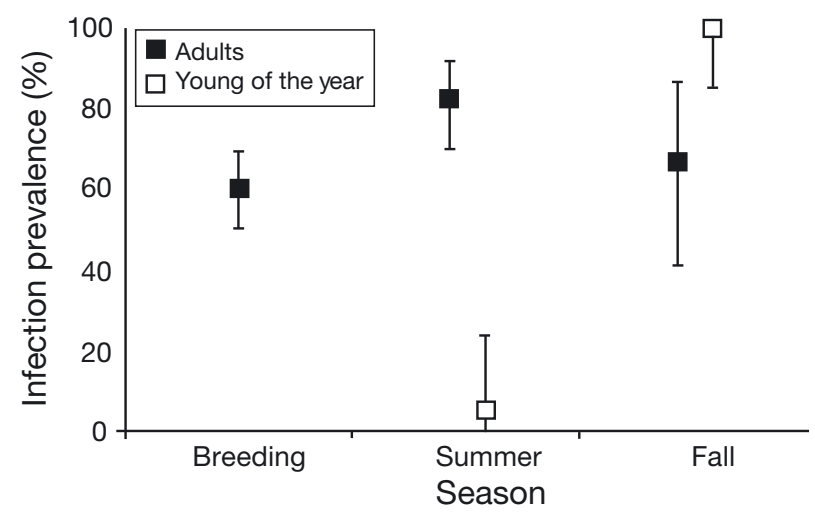

Fig. 2. Rana luteiventris. Prevalence of Batrachochytrium dendrobatidis across seasons and age classes (proportion of infected samples). Error bars represent 95\% confidence intervals

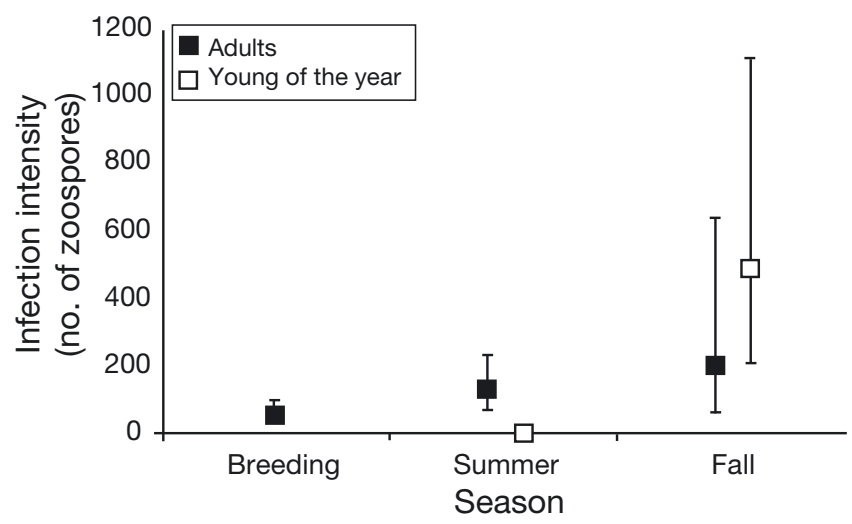

Fig. 3. Rana luteiventris. Intensity of Batrachochytrium dendrobatidis $(B d)$ infection across seasons and age classes (average number of $B d$ zoospores for infected samples). Error bars represent $95 \%$ confidence intervals

\section{Season}

Among adults, there was some evidence that $B d$ prevalence but not intensity varied seasonally. $B d$ prevalence showed weak evidence of a relationship with season after accounting for pond differences $\left(\chi_{2}^{2}=5.71, p=0.06\right.$; Fig. 2). Prevalence was higher in the summer $(83.0 \%, 95 \% \mathrm{CI}=70.2$ to $91.9 \%)$ than in the breeding season $(60.2 \%, 95 \% \mathrm{CI}=50.3$ to $69.5 \%$ ); estimates for the fall had a large variance due to smaller sample sizes $(66.7 \%, 95 \% \mathrm{CI}=41.0$ to $86.7 \%$ ). We did not detect a difference in intensity of adult $B d$ infection among seasons after accounting for pond $\left(\chi_{2}^{2}=2.11, p=0.35\right.$; Fig. 3$)$, although mean $B d$ intensity increased through the seasons; we found a mean intensity of 52 zoospores in the breeding season $(95 \% \mathrm{CI}=31$ to 86 zoospores), 117 zoospores in the summer $(95 \% \mathrm{CI}=$
66 to 208 zoospores), and 203 zoospores in the fall (95\% CI = 64 to 650 zoospores).

Although single-effect GLM analyses did not provide strong evidence that $B d$ dynamics varied seasonally, our AIC model selection analyses suggested that seasonality helps explain $B d$ infection dynamics. The most supported models of both $B d$ prevalence and intensity included both season and age class (after accounting for the random effect of pond, evidence weights $>0.70$ ), indicating that both factors are likely important for explaining $B d$ patterns in this system (Table 2).

\section{Environmental variables}

We did not detect a relationship between seasonal water temperature and $B d$ prevalence $\left(F_{1,17}=1.42, \mathrm{p}=\right.$ $0.25)$ or infection intensity $\left(F_{1,17}=1.64, \mathrm{p}=0.22\right)$. Average water temperature was $8.7^{\circ} \mathrm{C}$ in the spring $(95 \%$ $\mathrm{CI}=8.2$ to $\left.9.2^{\circ} \mathrm{C}\right), 19.8^{\circ} \mathrm{C}$ in summer $(95 \% \mathrm{CI}=18.2$ to $\left.21.4^{\circ} \mathrm{C}\right)$, and $8.9^{\circ} \mathrm{C}\left(95 \% \mathrm{CI}=-3.6\right.$ to $\left.14.2^{\circ} \mathrm{C}\right)$ in the fall season. Similarly, no relationship was detected between elevation and $B d$ prevalence $\left(F_{1,6}=0.018, \mathrm{p}=\right.$ $0.90)$ or intensity $\left(F_{1,6}=3.49, \mathrm{p}=0.12\right)$.

\section{DISCUSSION}

We investigated the prevalence and intensity of $B d$ infection of Rana luteiventris populations in northern Idaho to better understand disease dynamics across seasons, sexes, and age classes in a seasonal north temperate environment. Although we did not observe obvious clinical symptoms of chytridiomycosis in this species, we recorded the relatively ubiquitous presence of $B d$ in the focal $R$. luteiventris populations. All ponds sampled were infected with $B d$ in every season. We also observed differences in $B d$ prevalence and intensity among seasons, and in $B d$ prevalence and intensity across frog age classes, providing information on disease dynamics in the north temperate zone.

Patterns of infection in adult Rana luteiventris suggest that $B d$ is widespread and persists year to year in northern Idaho. Although our study occurred during a single year, prior surveys indicate that $B d$ has been present in this system since at least 2004. In our 2009 surveys $B d$ was present in at least $60 \%$ of adults sampled in each season. The high prevalence across seasons suggests that individual frogs may maintain their $B d$ loads over time and/or are highly susceptible to reinfection. The high $B d$ prevalence (if relatively low intensity) in the early spring also suggests that $B d$ persists through overwintering and that adults function as disease reservoirs across years. 
Table 2. Rana luteiventris. Evidence weights for mixed-effects models predicting prevalence and intensity of Batrachochytrium dendrobatidis infection at ponds in north Idaho. 'Age' is age class (late stage tadpole, metamorph, adult); 'Season' is when sampling occurred (spring, summer, fall; 'Pond' is a random effect. AIC: Akaike's Information Criterion

\begin{tabular}{|lccccc|}
\hline \multirow{2}{*}{ Model } & \multicolumn{2}{c}{ Prevalence } & & \multicolumn{2}{c|}{$\begin{array}{c}\text { Intensity } \\
\text { Evidence weight }\end{array}$} \\
\hline [Pond] Age, Season & 0 & 0.72 & & 0 & 0.84 \\
[Pond] Age & 1.9 & 0.28 & & 3.3 & 0.16 \\
[Pond] Season & 38.7 & 0 & & 40.8 & 0 \\
[Pond] & 42.3 & 0 & 68.0 & 0 \\
\hline
\end{tabular}

late stage tadpoles (low infection) and metamorphs (high infection). The differences between late stage tadpoles and metamorphs were particularly striking. Only a single late stage tadpole tested positive for $B d$ with a low intensity of 10 zoospores. In contrast, metamorphs were infected with relatively high intensity (average of 488 zoospores, more than double the average adult infection intensity). This rapid transition from low prevalence and intensity to high prevalence and intensity following metamorphosis is

Our ability to detect differences between the sexes may have been limited by relatively small sample sizes, but we found weak evidence for a difference in $B d$ prevalence (but not intensity) between the sexes with adult females more likely to be infected than males (87 versus $65 \%$ ). It is possible that behavior in the breeding season, when females may come in direct skin contact with multiple competing males (Davis \& Verrell 2005), can help explain the observed pattern. An alternative explanation for the increased prevalence in females is a differential host immune response, particularly if females devote energy to reproduction at the expense of immune function (Jönsson et al. 2009). However, both sexes contributed substantially to the $B d$ zoospore pool in these north Idaho ponds.

Patterns of prevalence and intensity in adults also provide insight into seasonal disease dynamics. $B d$ prevalence in adults was highest in the summer and lower in the spring and fall. When the adults emerge in the spring, $B d$ likely proliferates quickly because temperatures are increasing (favoring $B d$ growth) while frog immunity can still be suppressed from overwintering (Maniero \& Carey 1997). Some adult frogs may carry $B d$ through hibernation and adult prevalence may increase during the breeding season when many adults come into direct skin contact. The underlying mechanism causing decreased $B d$ prevalence in the fall remains unclear. It is possible that warmer summer temperatures allow for maximum immune activity to fight $B d$ infection (Anver \& Pond 1984) and/or that frogs may exhibit thermoregulatory basking behavior, which could reduce $B d$ infection (Richards-Zawacki 2010). While prevalence decreased in the fall, frogs that were infected in the fall had higher infection intensities than in other seasons. It is possible that only those frogs with lower $B d$ intensity were able to clear their infections in the warm summer months.

Comparisons across age classes revealed life-stage specific patterns of infection. Adults exhibited intermediate infection prevalence and intensity relative to dramatic and is consistent with observations in other studies (e.g. Marantelli et al. 2004, Rachowicz et al. 2006, Garner et al. 2009). There are 2 possible explanations for the rapid increase of infection prevalence and intensity in young of the year from summer to fall. Late stage tadpoles may harbor Bd infection not only in their keratinized mouthparts but also on their newly keratinized hind feet (Marantelli et al. 2004). Therefore, an existing $B d$ infection could increase within a single host as metamorphosis completes and skin becomes highly keratinized. Alternatively, late stage tadpoles may not harbor $B d$ infections but may become infected after metamorphosis is complete. Distinguishing between these alternatives would require isolating late stage tadpoles in a laboratory setting, swabbing their mouthparts and tracking infection progression through metamorphosis. Either way, our data demonstrate a dramatic increase in $B d$ infection immediately following metamorphosis, with metamorphs exhibiting a much higher $B d$ infection prevalence and intensity than adults. It is possible that the metamorph immune system, which is not yet mature, is less able to control $B d$ infection than the adult immune system. Amphibians such as Rana luteiventris that undergo metamorphosis quickly (to avoid desiccation in ephemeral ponds) may be at a further disadvantage with low white blood cell counts and increased susceptibility to pathogens (Gervasi \& Foufopoulos 2008). Metamorphs, thus, will enter hibernation with relatively high infection intensities and clearly represent a vulnerable age class.

The ecological effects of $B d$ infection on Rana luteiventris populations remain unknown. The molecular $B d$ assay does not differentiate between the presence of $B d$ on the skin and a clinical infection that impacts the animal's health (Smith 2007). Ranid frogs can exhibit a variety of responses when infected with $B d$. Some species, such as the mountain yellow-legged frog $R$. muscosa in the Sierra Nevada Mountains of California, are highly susceptible to chytridiomycosis and have experienced massive $B d$-related die-offs 
(Briggs et al. 2005). Other species, such as the invasive American bullfrog Lithobates catesbeiana are more resistant and may even serve as vectors for new $B d$ introductions (Daszak et al. 2004). Field studies of the Oregon spotted frog $R$. pretiosa, sister species to $R$. luteiventris, found that first-year metamorphs infected with $B d$ had poorer body condition than uninfected metamorphs, indicating that infection causes stress during overwintering (Pearl et al. 2009). Further ecological and laboratory studies are needed to determine whether there are lethal or sub-lethal effects of $B d$ on $R$. luteiventris. The high $B d$ prevalence, relatively moderate $B d$ intensity, lack of clinical symptoms of chytridiomycosis and no reported $B d$-related die-offs suggest that $R$. luteiventris is persisting with $B d$. However, $B d$ infection could make $R$. luteiventris more sensitive to other diseases or environmental stressors. Further study across years will be required to determine the stability of this host-pathogen interaction.

If, as it appears, Rana luteiventris is persisting with $B d$, there are several non-mutually exclusive alternative explanations for tolerance to $B d$ infection. First, local north Idaho $B d$ isolates may have attenuated virulence, as differences between $B d$ isolate virulence have been reported (Berger et al. 2005, Fisher et al. 2009). Second, $R$. luteiventris may be a relatively resistant host species; as discussed above, the susceptibility of ranid frogs to chytridiomycosis varies. Laboratory studies are required to determine the relative virulence of local north Idaho $B d$ to specific hosts and the clinical effects of $B d$ infection on $R$. luteiventris. Finally, environmental conditions in north Idaho may explain the high prevalence of $B d$ and its persistence with $R$. luteiventris. As in other highly seasonal north temperate environments (e.g. Rocky Mountains; Muths et al. 2008), Bd growth is likely suppressed in the winter when ponds are frozen over. However, local thermal conditions are overall quite advantageous for $B d$, with ambient air and water temperatures rarely high or low enough to be lethal. In fact, the active season for local amphibians corresponds almost exactly to the optimal temperature for $B d$ growth. Particularly in the summer, the ponds we sampled had an average water temperature of $19.9^{\circ} \mathrm{C}$, ideal thermal conditions for $B d$ to thrive (Piotrowski et al. 2004).

If additional research demonstrates that Rana luteiventris is a relatively $B d$-resistant species, then $R$. luteiventris could be a reservoir for pathogen transmission to other more ecologically sensitive species. For example, the boreal toad Anaxyrus boreas is sympatric with $R$. luteiventris in much of Idaho. A. boreas is known to be experiencing $B d$-related die-offs in other parts of its range (Muths et al. 2003), so monitoring $B d$ effects in Idaho populations is a priority. Currently, $B d$ has not been detected in some species in this area, such as the Coeur d'Alene salamander Plethodon idahoensis (C. S. Goldberg, L. P. Waits \& E. B. Rosenblum unpubl. data) and Rocky Mountain tailed frog Ascaphus montanus (Hossack et al. 2010) but more rigorous field surveys are needed to understand the community level impacts of $B d$ in this region.

Acknowledgements. This project was conducted under a State of Idaho Department of Fish and Game Wildlife Collecting Permit (\#040217) and an approved Animal Care and Use Protocol (\#2008-55). We thank the Rosenblum, Harmon and Waits laboratories of the University of Idaho for field assistance and comments on the manuscript. Funding was provided by a Berklund Undergraduate Research Award and a DeVleig Grant.

\section{LITERATURE CITED}

Anver MR, Pond CL (1984) Biology and diseases of amphibians. In: Fox JG, Cohen BJ, Loew FM (eds) Laboratory animal medicine. Academic Press, New York, NY, p 427-447

Bates D (2005) Fitting linear mixed models in R. R News 5:27-30

Berger L, Speare R, Daszak P, Green DE and others (1998) Chytridiomycosis causes amphibian mortality associated with population declines in the rain forests of Australia and Central America. Proc Natl Acad Sci USA 95: 9031-9036

Berger L, Speare R, Hines HB, Marantelli G and others (2004) Effect of season and temperature on mortality in amphibians due to chytridiomycosis. Aust Vet J 82:434-439

Berger L, Marantelli G, Skerratt LF, Speare R (2005) Virulence of the amphibian chytrid fungus Batrachochytrium dendrobatidis varies with the strain. Dis Aquat Org 68: 47-50

Boyle DG, Boyle DB, Olsen V, Morgan JAT, Hyatt AD (2004) Rapid quantitative detection of chytridiomycosis (Batrachochytrium dendrobatidis) in amphibian samples using real-time Taqman PCR assay. Dis Aquat Org 60:141-148

Briggs CJ, Vredenburg VT, Knapp RA, Rachowicz LJ (2005) Investigating the population-level effects of chytridiomycosis: an emerging infectious disease of amphibians. Ecology 86:3149-3159

Burnham KP, Anderson DR (2003) Model selection and multimodel inference: a practical information-theoretic approach, 2nd edn. Springer-Verlag, New York, NY

Daszak P, Strieby A, Cunningham AA, Longcore JE, Brown CC, Porter D (2004) Experimental evidence that the bullfrog (Rana catesbeiana) is a potential carrier of chytridiomycosis, an emerging fungal disease of amphibians. Herpetol J 14:201-207

Davis AB, Verrell PA (2005) Demography and reproductive ecology of the Columbia spotted frog (Rana luteiventris) across the Palouse. Can J Zool 83:702-711

Fisher MC, Bosch J, Zhikang Y, Stead DA and others (2009) Proteomic and phenotypic profiling of the amphibian pathogen Batrachochytrium dendrobatidis shows that genotype is linked to virulence. Mol Ecol 18:415-429

> Flajnik MF, Hsu E, Kaufman JF, Pasquier LD (1987) Changes in the immune system during late stage metamorphosis of Xenopus. Immunol Today 8:58-64

> Garner TJW, Walker S, Bosch J, Leech S, Rowcliffe JM, Cunningham AA, Fisher MC (2009) Life history tradeoffs influence mortality associated with the amphibian pathogen Batrachochytrium dendrobatidis. Oikos 118:783-791 
Gervasi SS, Foufopoulos J (2008) Costs of plasticity: responses to desiccation decrease post-late stage tadpoleic immune function in a pond-breeding amphibian. Funct Ecol 22: 100-108

Goldberg CS, Waits LP (2010) Comparative landscape genetics of two pond-breeding amphibian species in a highly modified agricultural landscape. Mol Ecol 19:3650-3663

Gosner KL (1960) A simplified table for staging anuran embryos and larvae with notes on identification. Herpetologica 16:183-190

- Hossack BR, Adams MJ, Campbell Grant EH, Pearl CA and others (2010) Low prevalence of chytrid fungus (Batrachochytrium dendrobatidis) in amphibians of U.S. headwater streams. J Herpetol 44:253-260

Hyatt AD, Boyle DG, Olsen V, Boyle DB and others (2007) Diagnostic assays and sampling protocols for the detection of Batrachochytrium dendrobatidis. Dis Aquat Org 73: 175-192

James TY, Litvintseva AP, Vilgalys R, Morgan JAT, Taylor JW (2009) Rapid global expansion of the fungal disease chytridiomycosis into declining and healthy amphibian populations. PLoS Pathog 5:e1000458

Jönsson KI, Herczeg G, O'Hara RB, Söderman F, ter Schure A, Larsson P, Merilä J (2009) Sexual patterns of prebreeding energy reserves in the common frog Rana temporaria along a latitudinal gradient. Ecography 32:831-839

Kriger KM, Hero JM (2008) Altitudinal distribution of chytrid (Batrachochytrium dendrobatidis) infection in subtropical Australian frogs. Austral Ecol 33:1022-1032

Kriger KM, Hines HB, Hyatt AD, Boyle DG, Hero JM (2006a) Techniques for detecting chytridiomycosis in wild frogs: comparing histology with real-time Taqman PCR. Dis Aquat Org 71:141-148

Kriger KM, Hero JM, Ashton KJ (2006b) Cost efficiency in the detection of chytridiomycosis using PCR assay. Dis Aquat Org 71:149-154

Lips KR, Brem F, Brenes R, Reeve JD and others (2006) Emerging infectious disease and the loss of biodiversity in a Neotropical amphibian community. Proc Natl Acad Sci USA 103:3165-3170

> Maniero GD, Carey C (1997) Changes in selected aspects of immune function in the leopard frog, Rana pipiens, associated with exposure to cold. J Comp Physiol B 167:256-263

Marantelli G, Berger L, Speare R, Keegan L (2004) Distribution of the amphibian chytrid Batrachochytrium dendrobatidis and keratin during tadpole development. Pac Conserv Biol 10:173-179

Mazzoni R, Cunningham AA, Daszak P, Apolo A, Perdomo E, Speranza G (2003) Emerging pathogen of wild amphibians in frogs (Rana catesbeiana) farmed for international trade. Emerg Infect Dis 9:995-998

Morehouse EA, James TY, Ganley ARD, Vilgalys R, Berger L, Murphy PJ, Longcore JE (2003) Multilocus sequence typing suggests the chytrid pathogen of amphibians is a recently emerged clone. Mol Ecol 12:395-403

Editorial responsibility: Cynthia Carey,

Boulder, Colorado, USA
Muths E, Corn PS, Pessier AP, Green DE (2003) Evidence for disease-related amphibian decline in Colorado. Biol Conserv 110:357-365

> Muths E, Pilliod DS, Livo LJ (2008) Distribution and environmental limitations of an amphibian pathogen in the Rocky Mountains, USA. Biol Conserv 141:1484-1492

Patla DA, Keinath D (2005) Columbia spotted frog (Rana luteiventris formerly $R$. pretiosa): a technical conservation assessment. USDA Forest Service, Rocky Mountain Region. Retrieved 31 Oct, 2009. www.fs.fed.us/r2/projects/ scp/assessments/columbiaspottedfrog.pdf

> Pearl CA, Bull EL, Green DE, Bowerman J, Adams MJ, Hyatt A, Wente WH (2007) Occurrence of the amphibian pathogen Batrachochytrium dendrobatidis in the Pacific Northwest. J Herpetol 41:145-149

Pearl CA, Bowerman J, Adams MJ, Chelgren ND (2009) Widespread occurrence of the chytrid fungus Batrachochytrium dendrobatidis on Oregon spotted frogs (Rana pretiosa). EcoHealth 6:209-218

> Picco AM, Collins JP (2008) Amphibian commerce as a likely source of pathogen pollution. Conserv Biol 22:1582-1589

> Piotrowski JS, Annis SL, Longcore JE (2004) Physiology of Batrachochytrium dendrobatidis, a chytrid pathogen of amphibians. Mycologia 96:9-15

R Development Core Team (2008) R: a language and environment for statistical computing. R Foundation for Statistical Computing, Vienna

Rachowicz LJ, Knapp RA, Morgan JAT, Stice MJ, Vredenburg VT, Parker JM, Briggs CJ (2006) Emerging infectious disease as a proximate cause of amphibian mass mortality. Ecology 87:1671-1683

Reaser JK, Pilliod DS (2005) Rana luteiventris, Columbia spotted frog. In: Lannoo MJ (ed) Amphibian declines: the conservation status of United States species. University of California Press, Berkeley, CA, p 559-563

> Richards-Zawacki CL (2010) Thermoregulatory behaviour affects prevalence of chytrid fungal infection in a wild population of Panamanian golden frogs. Proc Biol Sci 277:519-528

Rowley JJL, Alford RA (2007) Behaviour of Australian rainforest stream frogs may affect the transmission of chytridiomycosis. Dis Aquat Org 77:1-9

Schloegel LM, Hero JM, Berger L, Speare R, McDonald K, Daszak P (2006) The decline of the sharp-snouted day frog (Taudactylus acutirostris): the first documented case of extinction by infection in a free-ranging wildlife species? EcoHealth 3:35-40

Smith KG (2007) Use of quantitative PCR assays for amphibian chytrid detection: comment on Kriger et al. (2006 a,b). Dis Aquat Org 73:253-255

Woodhams DC, Alford RA, Marantelli G (2003) Emerging disease of amphibians cured by elevated body temperature. Dis Aquat Org 55:65-67

Zar JH (1984) Biostatistical analysis, 2nd edn. Prentice Hall, Englewood Cliffs, NJ

Submitted: April 22, 2010; Accepted: September 15, 2010 Proofs received from author(s): November 4, 2010 